HASSE, Franciane. A dimensão constitucional dos Princípio do Contraditório e da Ampla Defesa das pessoas jurídicas de direito privado perante os Tribunais de Contas da União (TCU) e Tribunal de Contas do Estado de Santa Catarina (TCESC). Revista Eletrônica Direito e Política, Programa de Pós-Graduação Stricto Sensu em Ciência Jurídica da UNIVALI, Itajaí, v.10, n.2, 10 quadrimestre de 2015. Disponível em: www.univali.br/direitoepolitica - ISSN 1980-7791.

\title{
A DIMENSÃO CONSTITUCIONAL DO PRINCÍPIO DO CONTRADITÓRIO E DA AMPLA DEFESA DAS PESSOAS JURÍDICAS DE DIREITO PRIVADO PERANTE OS TRIBUNAIS DE CONTAS DA UNIÃO (TCU) E TRIBUNAL DE CONTAS DO ESTADO DE SANTA CATARINA (TCESC)
}

\author{
THE DIMENSION OF THE CONSTITUTIONAL PRINCIPLE OF \\ CONTRADICTORY AND DEFENCE WIDE OF LEGAL ENTITIES OF PRIVATE \\ LAW BY THE UNION OF AUDITORS COURT (TCU) AND SANTA CATHERINE \\ STATE COURT OF AUDITORS (TCESC)
}

Franciane Hasse ${ }^{1}$

SUMÁRIO: Introdução; 1. Princípio do Contraditório e da Ampla Defesa; 2. Concessão e Permissão de Serviço Público; 3. Parceria Público-Privada (PPP); 4. Legislação Estadual de Santa Catarina referente às Parcerias Público-Privadas; 5. Tribunal de Contas; Considerações finais; Referências das fontes citadas.

RESUMO: O estudo tem por objetivo, defender a incidência do contraditório e da ampla defesa nos processos sujeitos ao Tribunal de Contas da União e do Tribunal de Contas do Estado de Santa Catarina. Inicia com a especificação do princípio constitucional do contraditório e da ampla defesa, onde qualquer processo, seja ele judicial ou administrativo, deverá permitir que as partes formalizem sua resposta em relação às acusações que Ihe são impostas. Ainda, o estudo identifica que para realizar alguns serviços públicos, o Poder Público se utiliza dos institutos de concessão, permissão e parcerias público-privadas, não sendo transferida a sua titularidade, mas sim a responsabilidade pela execução e por qualquer dano ou irregularidade que venha a surgir no decorrer do contrato. Visto que para a execução dos contratos, as pessoas jurídicas de direito privado necessitam de recursos públicos verifica-se que o Tribunal de Contas será o

\footnotetext{
${ }^{1}$ Advogada. Docente dos cursos de Direito e Sistemas de Informação do Centro Universitário para o Desenvolvimento do Alto Vale do Itajaí - UNIDAVI. Especialista em Direito Empresarial e dos Negócios pela Universidade do Vale do Itajaí - UNIVALI. Especialista em Direito Processual Civil pelo Instituto Catarinense de Pós-graduaç̧ão - ICPG. Bacharel em Direito pela Universidade para o Desenvolvimeto do Alto Vale do Itajaí - UNIDAVI. Bacharel em Sistemas de Informação pela Universidade para o Desenvolvimeto do Alto Vale do Itajaí - UNIDAVI. E-mail: francianehasse@gmail.com.
} 
HASSE, Franciane. A dimensão constitucional dos Princípio do Contraditório e da Ampla Defesa das pessoas jurídicas de direito privado perante os Tribunais de Contas da União (TCU) e Tribunal de Contas do Estado de Santa Catarina (TCESC). Revista Eletrônica Direito e Política, Programa de Pós-Graduação Stricto Sensu em Ciência Jurídica da UNIVALI, Itajaí, v.10, n.2, $1^{0}$ quadrimestre de 2015. Disponível em: www.univali.br/direitoepolitica - ISSN 1980-7791.

responsável pela fiscalização de sua aplicação. Por fim, conclui-se que o contraditório e a ampla defesa das pessoas jurídicas de direito privado é respeitada, inclusive, em processos administrativos no âmbito do Tribunal de Contas. A metodologia utilizada neste estudo foi a pesquisa bibliográfica.

Palavras-Chave: Poder Público; Parceria Público Privada; Contraditório; Ampla Defesa; Tribunal de Contas.

ABSTRACT: The study aims to defend the incidence of contradictory and legal defense in cases subject to the Court of Auditors of the Union and of the Court of the State of Santa Catarina. Starts with the specification of the constitutional principle of the contradictory and full defense, where any proceedings, whether judicial or administrative, should allow the parties to formalize their response regarding the charges imposed on him. Still, the study identifies that to make some public services, the Government used the granting institutes, permission and public-private partnerships, its ownership not being transferred, but the responsibility for implementation and for any damage or irregularity that may to arise in the course of the contract. As for the performance of contracts, legal entities of private law require public funds it appears that the Court will be responsible for overseeing its implementation. Finally, it is concluded that the contradictory and full defense of legal entities of private law is respected even in administrative proceedings in the Court of Auditors. The methodology used in this study was the literature.

Keywords: Government; Public Private Partnership; Contradictory; Wide Defense; Court of Auditors.

\section{INTRODUÇÃO}

Este artigo refere-se à garantia do contraditório e da ampla defesa das pessoas jurídicas de direito privado perante os Tribunais de Contas.

Inicialmente, em linhas gerais, apresentam-se as definições do contraditório e da ampla defesa e os parâmetros necessários para a execução de contratos entre o Poder Público e os concessionários, permissionários ou através de parcerias público-privadas, bem como analisa os aspectos mais importantes de acordo com a legislação em vigor, inclusive no que se refere às parcerias público-privadas do Estado de Santa Catarina.

Verificar-se-á que o princípio do contraditório e da ampla defesa é um princípio amparado constitucionalmente, sendo que, em todo processo deverá ser 
HASSE, Franciane. A dimensão constitucional dos Princípio do Contraditório e da Ampla Defesa das pessoas jurídicas de direito privado perante os Tribunais de Contas da União (TCU) e Tribunal de Contas do Estado de Santa Catarina (TCESC). Revista Eletrônica Direito e Política, Programa de Pós-Graduação Stricto Sensu em Ciência Jurídica da UNIVALI, Itajaí, v.10, n.2, 10 quadrimestre de 2015. Disponível em: www.univali.br/direitoepolitica - ISSN 1980-7791.

verificado e respeitado, pois as partes têm o direito ao acesso a todo o processo, para que assim, possam de forma fundamentada, responder às acusações que Ihes são impostas. Isto procede tanto no âmbito judicial quanto no âmbito administrativo, sendo este último o que caracteriza o estudo em questão. ${ }^{2}$

Quanto à concessão, permissão e parceria público-privada, dispõe o artigo que são institutos utilizados pelo Poder Público, para que possam executar alguns serviços públicos de maneira eficaz, satisfazendo os interesses da coletividade.

Assim, através de procedimento licitatório, na modalidade concorrência, será permitida a formalização do contrato entre o particular (pessoa física ou jurídica) e o Poder Público.

Porém, esclarece-se que a titularidade dos serviços manter-se-á com o Poder Público, transferindo-se somente a responsabilidade pela execução dos serviços públicos, sendo que deverá ser adequado ao pleno atendimento dos usuários, conforme as disposições contratuais previamente estabelecidas em procedimento licitatório.

Verifica-se, também, sobre a vinculação entre o Poder Público e as pessoas jurídicas de direito privado, para que, assim, identifiquem-se os responsáveis diante de um processo instaurado pelo Tribunal de Contas.

Tem-se por objetivo, defender a incidência do contraditório e da ampla defesa nos processos sujeitos ao Tribunal de Contas da União e do Tribunal de Contas do Estado de Santa Catarina.

Apesar do Tribunal de Contas não integrar o Poder Judiciário, verificar-se-á que o mesmo não está fora de cumprir determinados procedimentos, para que assim, possa finalizar com uma decisão fundamentada e coerente.

\footnotetext{
2 Nos processos perante o Tribunal de Contas da União asseguram-se o contraditório e a ampla defesa quando da decisão puder resultar anulação ou revogação de ato administrativo que beneficie o interessado, excetuada a apreciação da legalidade do ato de concessão inicial de aposentadoria, reforma e pensão. (Súmula Vinculante $n^{\circ} 3$ do STF - http://www.stf.jus.br, acessado em 08/11/2012)
} 
HASSE, Franciane. A dimensão constitucional dos Princípio do Contraditório e da Ampla Defesa das pessoas jurídicas de direito privado perante os Tribunais de Contas da União (TCU) e Tribunal de Contas do Estado de Santa Catarina (TCESC). Revista Eletrônica Direito e Política, Programa de Pós-Graduação Stricto Sensu em Ciência Jurídica da UNIVALI, Itajaí, v.10, n.2, 10 quadrimestre de 2015. Disponível em: www.univali.br/direitoepolitica - ISSN 1980-7791.

Assim, o Tribunal de Contas será o responsável pela fiscalização de um ato ou contrato que advenha de recursos do Poder Público.

Tem-se como fim, demonstrar a importância da garantia do contraditório e da ampla defesa, inclusive em processos administrativos, a fim de permitir, que o responsável tenha o direito de se manifestar de qualquer decisão proferida.

Nos casos dos contratos de concessão, permissão e parceria público-privada, notar-se-á que as pessoas jurídicas de direito privado estão amparadas pelo princípio do contraditório e da ampla defesa, mesmo nos processos administrativos tramitados no âmbito do Tribunal de Contas. Salienta-se, todavia, que todo o procedimento submetido à deliberação do Tribunal de Contas será organizado em processo, porém, suas decisões são meros atos administrativos.

Quanto à metodologia, utiliza-se a de pesquisa bibliográfica, com embasamento em um referencial teórico de obras de doutrinadores nas áreas de direito administrativo e de direito processual civil, assim como da legislação vigente, referente aos institutos em questão.

\section{PRINCÍPIOS DO CONTRADITÓRIO E DA AMPLA DEFESA NO PROCESSO ADMINISTRATIVO}

Para definir os princípios do contraditório e da ampla defesa, de forma singela, relata-se que, para toda ação existe uma contra-ação, ou seja, sempre que houver um processo regular interposto por uma parte, a outra terá o direito de oferecer resposta.

É esta bilateralidade, que propicia o conhecimento da existência das contrariedades em questão, é ainda a garantidora da paridade de tratamento entre as partes, fazendo com que a parte adversa tome conhecimento do porquê Ihe foi imposta uma ação ou um requerimento e que este "requerido" terá o 
HASSE, Franciane. A dimensão constitucional dos Princípio do Contraditório e da Ampla Defesa das pessoas jurídicas de direito privado perante os Tribunais de Contas da União (TCU) e Tribunal de Contas do Estado de Santa Catarina (TCESC). Revista Eletrônica Direito e Política, Programa de Pós-Graduação Stricto Sensu em Ciência Jurídica da UNIVALI, Itajaí, v.10, n.2, 10 quadrimestre de 2015. Disponível em: www.univali.br/direitoepolitica - ISSN 1980-7791.

direito de defender-se perante as narrativas impostas mediante cópia de peça processual (petição inicial ${ }^{3}$ ) ou requerimento administrativo.

À luz dos dizeres de Santos:

A bilateralidade da ação gera a bilateralidade do processo. Em todo processo há, ao menos, duas partes - autor e réu. E se é o autor quem, invocando a tutela jurisdicional, instaura a relação processual, não é menos verdade que esta se completa com a citação do réu. Colocado entre as partes, eqüidistante delas, o juiz, por força do seu dever de imparcialidade, ouvindo uma não deverá deixar de ouvir outra parte - audiaturet altera pars. ${ }^{4}$

Em um outro momento, tratando sobre a igualdade das partes, no que se refere à argumentação propriamente dita e naturalmente ao direito de defesa, descreve Theodoro Júnior:

[...] o principal consectário do tratamento igualitário das partes se realiza através do contraditório, que consiste na necessidade de ouvir a pessoa perante a qual será proferida a decisão, garantindo-Ihe o pleno direito de defesa e de pronunciamento durante todo o curso do processo. [...] quando se afirma o caráter absoluto do princípio do contraditório, o que se pretende dizer é que nenhum processo ou procedimento pode ser disciplinado sem assegurar às partes a regra de isonomia no exercício das faculdades processuais. ${ }^{5}$

Nota-se que, os princípios do contraditório e da ampla defesa estão assegurados pelo mesmo dispositivo constitucional: o inciso $\mathrm{LV}^{6}$, artigo 50, da Constituição Federal.

\footnotetext{
3 "Um dos pressupostos da existência do processo é a petição inicial, instrumento da demanda, através do qual o autor exerce o direito de ação e invoca a prestação da tutela jurisdicional." (WAMBIER, op. cit., p. 213)

4 SANTOS, Moacyr Amaral. Primeiras linhas de direito processual civil. v. 2. 23. ed. rev. e atual. São Paulo: Saraiva, 2004. p. 74.

5 THEODORO, Junior, Humberto. Curso de direito processual civil. Rio de Janeiro: Forense, 2004. p. 88

6 "[...] aos litigantes, em processo judicial ou administrativo, e aos acusados em geral são assegurados o contraditório e a ampla defesa, com os meios e recursos a ela inerentes." (art. 50, LV, da CF). BRASIL. Constituição (1988). Constituição da República Federativa do Brasil. Brasília, DF: Senado Federal: Centro Gráfico, 1988.
} 
HASSE, Franciane. A dimensão constitucional dos Princípio do Contraditório e da Ampla Defesa das pessoas jurídicas de direito privado perante os Tribunais de Contas da União (TCU) e Tribunal de Contas do Estado de Santa Catarina (TCESC). Revista Eletrônica Direito e Política, Programa de Pós-Graduação Stricto Sensu em Ciência Jurídica da UNIVALI, Itajaí, v.10, n.2, $1^{\circ}$ quadrimestre de 2015. Disponível em: www.univali.br/direitoepolitica - ISSN 1980-7791.

Estando estes intimamente ligados, o juiz ou autoridade competente, terá maiores condições de analisar e julgar o fato, pois que cada uma das partes estará agindo a seu favor e trazendo aos autos ou ao processo administrativo, os argumentos para que se deduza a lógica formal de composição da lide, buscando a solução eficaz desta.

Acerca da intimidade entre contraditório e ampla defesa, da questionabilidade e de qual se origina de qual, se é que se pode deduzir, veja-se os ensinamentos de Grinover:

Num determinado enfoque, é inquestionável que é do contraditório que brota a própria defesa. Desdobrando-se o contraditório em dois momentos - a informação e a possibilidade de reação - não há como negar que o conhecimento, ínsito no contraditório, é pressuposto para o exercício da defesa. Mas, de outro ponto de vista, é igualmente válido afirmar que a defesa é que garante o contraditório, conquanto nele se manifeste. Isto porque a defesa representa, na realidade, um aspecto integrante do próprio direito de ação, quais face e verso da mesma medalha, até porque não se pode falar em ação senão com relação à defesa, baseando-se a atuação de ambas as garantias sobre componentes idênticas. ${ }^{7}$

Os princípios do contraditório e da ampla defesa configuram-se a partir do momento em que o demandado (a parte contrária) é citado (para as hipóteses da legislação geral) e notificado (para as hipóteses dos procedimentos administrativos) sendo que fica a encargo deste oferecer sua defesa (importante destacar que existe prazo para a propositura desta defesa e que estes prazos estão especificados nas legislações pertinentes à cada situação).

Porém, mesmo que o réu (demandado, parte contrária) não se pronuncie, seja no processo civil ou no processo administrativo (Lei $n^{\circ} 9.784$, de 29 de janeiro de 1999$)^{8}$, ou seja, se este for revel, o instituto atingiu seu fim, tendo a parte

\footnotetext{
7 GRINOVER, Ada Pellegrini. O processo constitucional em marcha: contraditório e ampla defesa em cem julgados do tribunal de alçada criminal de São Paulo. São Paulo: Max Limonad, 1985. p. 10.

${ }^{8}$ BRASIL. Lei $\mathbf{n}^{\circ} \mathbf{9 . 7 8 4}$, de 29 de janeiro de 1999. Regula o processo administrativo no âmbito da Administração Pública Federal. <http://www.planalto.gov.br/ccivil_03/leis/19784.htm> Acesso em 08 nov 2012.
} 
HASSE, Franciane. A dimensão constitucional dos Princípio do Contraditório e da Ampla Defesa das pessoas jurídicas de direito privado perante os Tribunais de Contas da União (TCU) e Tribunal de Contas do Estado de Santa Catarina (TCESC). Revista Eletrônica Direito e Política, Programa de Pós-Graduação Stricto Sensu em Ciência Jurídica da UNIVALI, Itajaí, v.10, n.2, 10 quadrimestre de 2015. Disponível em: www.univali.br/direitoepolitica - ISSN 1980-7791.

citada oportunidade de tomar ciência e de manifestar-se quanto às alegações a ele impostas.

De outra banda, poderá o juiz deferir tutela antecipada pelo desígnio do inaudita altera pars ${ }^{9}$, apesar disso, não se acha ferido os princípios do contraditório e da ampla defesa, por conseguinte, terá ocasião pertinente de interpor manifestação posterior no processo, podendo serem ressarcidos eminentes prejuízos àquele que não foi ouvido.

\section{CONCESSÃo E PERMISSÃo dE SERVIÇO PÚBLICO}

A Lei n 8.987, de 13 de fevereiro de 1995, dispõe sobre o regime de concessão e permissão da prestação de serviços públicos, estabelecendo normas e diretrizes no que concerne à descentralização da prestação dos serviços públicos para particulares. ${ }^{10}$

Porém, o Poder Público mantém-se na titularidade da prestação do serviço, ditando as regras de execução, fiscalizando e aplicando sanções, se necessário.

O Poder Público, desta forma, precisa se valer destes institutos para suprir as necessidades da coletividade, devido à elevada gama de serviços necessários à utilidade pública.

Para melhor entendimento, Celso Antônio Bandeira de Mello conceitua concessão da seguinte forma:

Concessão de serviço público é o instituto através do qual o Estado atribui o exercício de um serviço público a alguém que aceita prestá-lo em nome próprio, por sua conta e risco, nas condições fixadas e alteráveis unilateralmente pelo Poder Público, mas sob garantia contratual de um equilíbrio econômico-financeiro, remunerando-se pela própria

\footnotetext{
${ }^{9}$ Sem ouvir a outra parte. SILVA. de Plácido. Vocabulário jurídico. 26. ed. SLAIBI FILHO. Nagib; CARVALHO. Gláucia. (atualizadores). Rio de Janeiro: Forense, 2005. p. 721.

10 BRASIL. Lei $n^{\circ}$ 8.987, de 13 de fevereiro de 1995. Estabelece o regime de concessão e permissão da prestação de serviços públicos. Disponível em: <http://www.planalto.gov.br/ccivil_03/leis/L8987cons.htm>. Acesso em: 08 nov. 2012.
} 
HASSE, Franciane. A dimensão constitucional dos Princípio do Contraditório e da Ampla Defesa das pessoas jurídicas de direito privado perante os Tribunais de Contas da União (TCU) e Tribunal de Contas do Estado de Santa Catarina (TCESC). Revista Eletrônica Direito e Política, Programa de Pós-Graduação Stricto Sensu em Ciência Jurídica da UNIVALI, Itajaí, v.10, n.2, 10 quadrimestre de 2015. Disponível em: www.univali.br/direitoepolitica - ISSN 1980-7791.

exploração do serviço, em geral e basicamente mediante tarifas cobradas diretamente dos usuários do serviço. ${ }^{11}$

E o mesmo autor conceitua permissão da seguinte forma:

Permissão de serviço público, segundo conceito tradicionalmente acolhido pela doutrina, é ato unilateral e precário, intuitu personae, através do qual o Poder Público transfere a alguém o desempenho de um serviço de sua alçada, proporcionando à moda do que faz na concessão, a possibilidade de cobrança de tarifas dos usuários. ${ }^{12}$

A Lei n 8.987/1995, por sua vez, em seu artigo 20, inciso II, designa:

Art. $2^{\circ}[\ldots]$

II - concessão de serviço público: a delegação de sua prestação, feita pelo poder concedente, mediante licitação, na modalidade de concorrência, à pessoa jurídica ou consórcio de empresas que demonstre capacidade para seu desempenho, por sua conta e risco e por prazo determinado.

$[\ldots]$

IV - permissão de serviço público: a delegação, a título precário, mediante licitação da prestação de serviços públicos, feita pelo poder concedente à pessoa física ou jurídica que demonstre capacidade para seu desempenho, por sua conta e risco. ${ }^{13}$

A caracterização de concessão e permissão de serviço público ocorre com o intuito da prestação de serviços suprir as necessidades do interesse público em geral, sendo a concessão através de uma pessoa jurídica criada por um particular ou consórcio de empresas (sociedade civil, comercial ou industrial) e a permissão através de uma pessoa física ou jurídica.

\footnotetext{
${ }^{11}$ MELLO, Celso Antônio Bandeira de. Curso de direito administrativo. 25. ed. rev. e atual. São Paulo: Malheiros Editores, 2007. p. 690.

12 MELLO, Celso Antônio Bandeira de. Curso de direito administrativo. 17. ed. rev. e atual. São Paulo: Malheiros Editores, 2004. p. 701.

13 BRASIL. Lei n 8.987, de 13 de fevereiro de 1995. Estabelece o regime de concessão e permissão da prestação de serviços públicos. Disponível em: <http://www.planalto.gov.br/ccivil_03/leis/L8987cons.htm>. Acesso em: 08 nov. 2012.
} 
HASSE, Franciane. A dimensão constitucional dos Princípio do Contraditório e da Ampla Defesa das pessoas jurídicas de direito privado perante os Tribunais de Contas da União (TCU) e Tribunal de Contas do Estado de Santa Catarina (TCESC). Revista Eletrônica Direito e Política, Programa de Pós-Graduação Stricto Sensu em Ciência Jurídica da UNIVALI, Itajaí, v.10, n.2, 10 quadrimestre de 2015. Disponível em: www.univali.br/direitoepolitica - ISSN 1980-7791.

A Constituição Federal, em seu artigo $175^{14}$, instituiu que o contrato entre o Poder Público e o concessionário ou permissionário deverá ser precedido de licitação.

Ocorre que, tanto na concessão quanto na permissão, não há a transferência da titularidade do serviço para o particular, pois o serviço permanece sendo de caráter público, sendo que somente o exercício, a execução da atividade pública é que fica sob a responsabilidade do concessionário ou permissionário.

Assim, a gestão do serviço será efetuada pelo concessionário ou pelo permissionário, respondendo perante terceiros e ao próprio Poder Público concedente, pelas obrigações ou por danos causados.

Verifica-se, portanto, que a concessão ou permissão torna-se uma forma do Poder Público obter a colaboração dos particulares no desempenho dos serviços públicos.

Assim, o pagamento do concessionário ou permissionário é efetuado através da exploração do serviço, por meio de tarifas cobradas dos usuários pelos serviços prestados.

Entretanto, a fixação das tarifas deve seguir o princípio do equilíbrio, devendo ser suficiente para remunerar o concessionário ou permissionário, sem onerar excessivamente aos usuários e sem transferir um ônus excessivo ao concessionário ou permissionário, seguindo os parâmetros previamente especificados no procedimento licitatório.

O contrato de concessão não pode ser desfeito a qualquer momento, pois há um prazo certo e determinado. Os motivos para rescisão do contrato devem ser expressamente apresentados, demonstrando a existência de pressupostos suficientes para tal fim.

\footnotetext{
14"Art. 175 - Incumbe ao Poder Público, na forma da lei, diretamente ou sob regime de concessão ou permissão, sempre através de licitação, a prestação de serviços públicos." BRASIL. Constituição (1988). Constituição da República Federativa do Brasil. Brasília, DF: Senado Federal: Centro Gráfico, 1988.
} 
HASSE, Franciane. A dimensão constitucional dos Princípio do Contraditório e da Ampla Defesa das pessoas jurídicas de direito privado perante os Tribunais de Contas da União (TCU) e Tribunal de Contas do Estado de Santa Catarina (TCESC). Revista Eletrônica Direito e Política, Programa de Pós-Graduação Stricto Sensu em Ciência Jurídica da UNIVALI, Itajaí, v.10, n.2, 10 quadrimestre de 2015. Disponível em: www.univali.br/direitoepolitica - ISSN 1980-7791.

Diferentemente da concessão, a permissão pode ser desfeita a qualquer momento unilateralmente pelo poder concedente, pois não há um prazo certo e determinado.

O artigo 60, da Lei n 8.987/1995, dispõe que toda concessão ou permissão pressupõe a prestação de serviço adequado ao pleno atendimento dos usuários, sendo que, "serviço adequado é o que satisfaz as condições de regularidade, continuidade, eficiência, segurança, atualidade, generalidade, cortesia na sua prestação e modicidade das tarifas". ${ }^{15}$

Ainda no que concerne à adequação do serviço, Marçal Justen Filho elucidou de forma clara, descrevendo:

Adequação consiste, basicamente, na eficiência do ponto de vista técnico-econômico. A atividade deve ser estruturada segundo as regras técnicas a ela pertinentes e de modo a que se constitua em meio causalmente próprio para satisfazer necessidades dos usuários. A atividade em que se materializa o serviço público é um meio-causa que deve conduzir a um fim-conseqüência. Não será adequado o serviço que não for apto a satisfazer, do ponto de vista técnico, a necessidade que motivou sua instituição. ${ }^{16}$

Desta forma, é importante frisar que o serviço deve ser prestado de forma a satisfazer os anseios da coletividade, pois os usuários do serviço são os principais fiscalizadores de tal atuação.

\footnotetext{
15 BRASIL. Lei $n^{\circ}$ 8.987, de 13 de fevereiro de 1995. Estabelece o regime de concessão e permissão da prestação de serviços públicos. Disponível em: <http://www.planalto.gov.br/ccivil_03/leis/L8987cons.htm>. Acesso em: 08 nov. 2012.
}

16 JUSTEN FILHO, Marçal. Teoria geral das concessões de serviço público. São Paulo: Dialética, 2003. p. 305. 
HASSE, Franciane. A dimensão constitucional dos Princípio do Contraditório e da Ampla Defesa das pessoas jurídicas de direito privado perante os Tribunais de Contas da União (TCU) e Tribunal de Contas do Estado de Santa Catarina (TCESC). Revista Eletrônica Direito e Política, Programa de Pós-Graduação Stricto Sensu em Ciência Jurídica da UNIVALI, Itajaí, v.10, n.2, 10 quadrimestre de 2015. Disponível em: www.univali.br/direitoepolitica - ISSN 1980-7791.

\section{PARCERIA PÚBLICO-PRIVADA (PPP)}

A Lei $n^{\circ} 11.079$, de 30 de dezembro de 2004, institui normas gerais para licitação e contratação de parceria público-privada no âmbito da administração pública. ${ }^{17}$

A parceria público-privada tem por finalidade viabilizar a implementação de projetos de alto risco, visto que em virtude de outras prioridades, o Poder Público não possui condições de realizá-los sozinho e nem o setor privado, em virtude dos recursos necessários.

As parcerias público-privadas envolvem a Administração direta ou indireta e a pessoa jurídica de direito privado. Sendo que a formalização contratual também deve ser precedida de procedimento licitatório, na modalidade de concorrência, conforme determinado no artigo 10 , da Lei n $11.079 / 2004 .{ }^{18}$

O artigo $2^{\circ}$, da referida Lei, define parceria público-privada da seguinte forma:

Art. $2^{\circ}$ Parceria público-privada é o contrato administrativo de concessão, na modalidade patrocinada ou administrativa.

$\S 10$ Concessão patrocinada é a concessão de serviços públicos ou de obras públicas de que trata a Lei n8.987, de 13 de fevereiro de 1995, quando envolver, adicionalmente à tarifa cobrada dos usuários contraprestação pecuniária do parceiro público ao parceiro privado.

$\S 2^{\circ}$ Concessão administrativa é o contrato de prestação de serviços de que a Administração Pública seja a usuária direta ou indireta, ainda que envolva execução de obra ou fornecimento e instalação de bens. ${ }^{19}$

\footnotetext{
17 BRASIL. Lei n 11.079, de 30 de dezembro de 2004. Institui normas gerais para licitação e contratação de parceria público-privada no âmbito da administração pública. Disponível em: <http://www.planalto.gov.br/ccivil_03/_ato2004-2006/2004/lei//11079.htm>. Acesso em: 08 nov. 2012.

18 BRASIL. Lei no 11.079, de 30 de dezembro de 2004. Institui normas gerais para licitação e contratação de parceria público-privada no âmbito da administração pública. Disponível em: <http://www.planalto.gov.br/ccivil_03/_ato2004-2006/2004/lei/l11079.htm>. Acesso em: 08 nov. 2012.

19 BRASIL. Lei $n^{\circ} 11.079$, de 30 de dezembro de 2004. Institui normas gerais para licitação e contratação de parceria público-privada no âmbito da administração pública. Disponível em: <http://www.planalto.gov.br/ccivil_03/_ato2004-2006/2004/lei//11079.htm>. Acesso em: 08 nov. 2012.
} 
HASSE, Franciane. A dimensão constitucional dos Princípio do Contraditório e da Ampla Defesa das pessoas jurídicas de direito privado perante os Tribunais de Contas da União (TCU) e Tribunal de Contas do Estado de Santa Catarina (TCESC). Revista Eletrônica Direito e Política, Programa de Pós-Graduação Stricto Sensu em Ciência Jurídica da UNIVALI, Itajaí, v.10, n.2, 10 quadrimestre de 2015. Disponível em: www.univali.br/direitoepolitica - ISSN 1980-7791.

Neste caso, há uma parceria na execução dos serviços ou obra entre o Poder Público e a pessoa jurídica de direito privado. Em contrapartida, há uma remuneração periódica paga pelo Poder Público à pessoa jurídica, de acordo com o seu desempenho no período de referência.

A Lei n $11.079 / 2004$ estabelece alguns requisitos para que seja possível a contratação por meio desta parceria, tais como o valor contratual que deve ser superior a 20 (vinte) milhões de reais (artigo $2^{\circ}$, $\$^{\circ}$, I) e, o prazo de vigência contratual que não deve ser inferior a 5 (cinco) anos e nem superior a 35 (trinta e cinco) anos (artigo $2^{\circ}, \S^{\circ}$, II e art. 50, I). ${ }^{20}$

Já o artigo 11, da Lei n 11.079/2004, determina que o instrumento convocatório poderá prever mecanismos privados de resolução de disputas, inclusive a arbitragem, para dirimir conflitos oriundos ou relacionados ao contrato, sendo que a arbitragem somente será permitida se as questões não forem relacionadas aos bens e interesses públicos portadores da condição de indisponibilidade. ${ }^{21}$

Importante lembrar que a arbitragem é um meio de facilitar a resolução de um conflito, onde as partes, de livre e espontânea vontade, elegem um terceiro especializado no assunto em questão (o árbitro ou Tribunal Arbitral) para que este o resolva, de forma imparcial e confidencial.

A referida Lei ainda prevê que seja instituído, por decreto, um órgão gestor de parcerias público-privadas federais para definir os serviços prioritários, disciplinar os procedimentos para celebração dos contratos, autorizar os procedimentos licitatórios e apreciar os relatórios de execução contratual, favorecendo, assim, a agilidade e eficiência nas ações decorrentes de tal parceria. ${ }^{22}$

\footnotetext{
20 BRASIL. Lei $\mathbf{n}^{\circ} \mathbf{1 1 . 0 7 9}$, de 30 de dezembro de 2004. Institui normas gerais para licitação e contratação de parceria público-privada no âmbito da administração pública. Disponível em: <http://www.planalto.gov.br/ccivil_03/_ato2004-2006/2004/lei//11079.htm>. Acesso em: 08 nov. 2012.

21 BRASIL. Lei no 11.079, de 30 de dezembro de 2004. Institui normas gerais para licitação e contratação de parceria público-privada no âmbito da administração pública. Disponível em: <http://www.planalto.gov.br/ccivil_03/_ato2004-2006/2004/lei//11079.htm>. Acesso em: 08 nov. 2012.

22 BRASIL. Lei n’ 11.079, de 30 de dezembro de 2004. Institui normas gerais para licitação e contratação de parceria público-privada no âmbito da administração pública. Disponível em:
} 
HASSE, Franciane. A dimensão constitucional dos Princípio do Contraditório e da Ampla Defesa das pessoas jurídicas de direito privado perante os Tribunais de Contas da União (TCU) e Tribunal de Contas do Estado de Santa Catarina (TCESC). Revista Eletrônica Direito e Política, Programa de Pós-Graduação Stricto Sensu em Ciência Jurídica da UNIVALI, Itajaí, v.10, n.2, $1^{\circ}$ quadrimestre de 2015. Disponível em: www.univali.br/direitoepolitica - ISSN 1980-7791.

Ainda, este órgão gestor deverá remeter ao Congresso Nacional e ao Tribunal de Contas da União, com periodicidade anual, relatórios de desempenho dos contratos de parcerias público-privadas. ${ }^{23}$

\section{LEGISLAÇÃo ESTADUAL DE SANTA CATARINA REFERENTE Às PARCERIAS PÚBLICO-PRIVADAS}

Os Estados-membros podem legislar a respeito da parceria público-privada, com fulcro nos artigos 25 e 30, I e II da Constituição Federal/88. ${ }^{24}$

A Lei n 12.930, de 04 de fevereiro de 2004, instituiu o marco regulatório dos programas de parcerias público-privadas no âmbito do Estado de Santa Catarina. ${ }^{25}$

A referida lei estadual, estabelece em seu artigo $3^{\circ}, \S 1^{\circ}$, que a modalidade contratual poderá ser utilizada individual, conjunta ou concomitantemente em um mesmo projeto de parceria público-privada, podendo submeter-se a um ou mais processos licitatórios.

A Lei estadual aponta, em seu artigo $3^{\circ}$, os objetos que são possíveis da parceria público-privada, mas não especifica quais são as áreas em que esta parceria poderá ser desenvolvida. Assim, o Decreto estadual n 1.932, de 14 de junho de 2004 , elenca essas áreas em seu artigo 40, $\S 1^{\circ}$, conforme a seguir transcrito.

Art. $4^{\circ}[\ldots]$

<http://www.planalto.gov.br/ccivil_03/_ato2004-2006/2004/lei/l11079.htm>. Acesso em: 08 nov. 2012.

${ }^{23}$ BRASIL. Lei no 11.079 , de 30 de dezembro de 2004. Institui normas gerais para licitação e contratação de parceria público-privada no âmbito da administração pública. Disponível em: <http://www.planalto.gov.br/ccivil_03/_ato2004-2006/2004/lei//11079.htm>. Acesso em: 08 nov. 2012.

24 BRASIL. Constituição (1988). Constituição da República Federativa do Brasil. Brasília, DF: Senado Federal: Centro Gráfico, 1988.

25 MUKAI, Sylvio Toshiro. Parcerias público-privadas: comentários à Lei Federal $\mathbf{n}^{\circ}$ 11.079/04, às Leis Estaduais de Minas Gerais, Santa Catarina, São Paulo, Distrito Federal, Goiás, Bahia, Ceará, Rio Grande do Sul e à Lei Municipal de Vitória/ES. Rio de Janeiro: Forense Universitária, 2005. 
HASSE, Franciane. A dimensão constitucional dos Princípio do Contraditório e da Ampla Defesa das pessoas jurídicas de direito privado perante os Tribunais de Contas da União (TCU) e Tribunal de Contas do Estado de Santa Catarina (TCESC). Revista Eletrônica Direito e Política, Programa de Pós-Graduação Stricto Sensu em Ciência Jurídica da UNIVALI, Itajaí, v.10, n.2, 10 quadrimestre de 2015. Disponível em: www.univali.br/direitoepolitica - ISSN 1980-7791.

$\S 1^{\circ}$ As atividades descritas nos incisos do caput deste artigo poderão ser desenvolvidas, preferencialmente, nas seguintes áreas:

I - educação, saúde e assistência social;

II - infra-estrutura de transportes;

III - saneamento básico e meio ambiente;

IV - segurança, penitenciária, defesa e justiça;

V - ciência, pesquisa e tecnologia;

VI - agronegócio, especialmente na agricultura irrigada e na agro-industrialização;

VII - planejamento e administração; e

VIII - outras áreas públicas de interesse social ou econômico. (Decreto estadual $n^{\circ} 1.932$, de 14 de junho de $2004)^{26}$

O referido Decreto criou o Comitê Gestor de Parcerias Público-Privadas - CGPPP, que é vinculado ao gabinete do governador, o qual definirá os procedimentos para a contratação de parcerias público-privadas (avaliando e autorizando o processo licitatório), elaborando o Plano Estadual de Parcerias Público-Privadas, que definirá as atividades, obras ou serviços considerados prioritários a serem executados sob o regime de parceria. ${ }^{27}$

Ainda, é importante ressaltar, que o contrato de parceria público-privada somente poderá ser celebrado se o seu objeto estiver previsto nos Planos de Desenvolvimento Regional e na Lei do Plano Plurianual - PPA. ${ }^{28}$

${ }^{26}$ BRASIL. DECRETO No 1.932, de 14 de junho de 2004. Regulamenta a Lei no. 12.930, de 04 de fevereiro, de 2004, que institui o marco regulatório dos programas de parcerias público-privada no âmbito do Estado de Santa Catarina, entre outras providências. Disponível em: < http://www.planejamento.gov.br/secretarias/upload/Arquivos/ppp/legislacao/estadual/lei_1932_20 04.pdf> Acesso em 08 nov. 2012.

27 BRASIL. DECRETO No 1.932, de 14 de junho de 2004. Regulamenta a Lei no. 12.930, de 04 de fevereiro, de 2004, que institui o marco regulatório dos programas de parcerias público-privada no âmbito do Estado de Santa Catarina, entre outras providências. Disponível em: < http://www.planejamento.gov.br/secretarias/upload/Arquivos/ppp/legislacao/estadual/lei_1932_20 04.pdf> Acesso em 08 nov. 2012.

28 BRASIL. DECRETO No 1.932, de 14 de junho de 2004. Regulamenta a Lei no. 12.930, de 04 de fevereiro, de 2004, que institui o marco regulatório dos programas de parcerias público-privada 
HASSE, Franciane. A dimensão constitucional dos Princípio do Contraditório e da Ampla Defesa das pessoas jurídicas de direito privado perante os Tribunais de Contas da União (TCU) e Tribunal de Contas do Estado de Santa Catarina (TCESC). Revista Eletrônica Direito e Política, Programa de Pós-Graduação Stricto Sensu em Ciência Jurídica da UNIVALI, Itajaí, v.10, n.2, 10 quadrimestre de 2015. Disponível em: www.univali.br/direitoepolitica - ISSN 1980-7791.

Com relação aos mecanismos de solução de divergências contratuais, o artigo 10, III, e, da Lei estadual n 12.930/2004 prevê a adoção da arbitragem, sem maiores definições. Já o Decreto estadual n 1.932/2004 especifica a arbitragem como um meio possível de utilização (artigo $7^{\circ}$ ), onde os árbitros serão escolhidos dentre pessoas físicas e reconhecida idoneidade e conhecimento da matéria, de acordo com as regras de arbitragem de órgão arbitral institucional ou entidade especializada, cujo foro será a capital do Estado (artigo 70, $\S \S 1^{\circ} \mathrm{e}$ $\left.2^{0}\right) .^{29}$

Para os demais procedimentos, a legislação estadual adota os parâmetros especificados na Lei $n^{\circ} 11.079 / 2004 .^{30}$

\section{TRIBUNAL DE CONTAS}

A Constituição Federal/88, em seus artigos 70 a 75, dispõe sobre a fiscalização contábil, financeira e orçamentária da União e demais entidades da administração direta e indireta, exercida pelo Congresso Nacional, mediante controle externo exercido pelo Tribunal de Contas da União, visando, desta forma, fiscalizar as contas referentes à arrecadação, guarda, gerenciamento ou administração de pecúnia, bens e valores públicos. ${ }^{31}$

no âmbito do Estado de Santa Catarina, entre outras providências. Disponível em: < http://www.planejamento.gov.br/secretarias/upload/Arquivos/ppp/legislacao/estadual/lei_1932_20 04.pdf> Acesso em 08 nov. 2012.

${ }^{29}$ BRASIL. DECRETO No 1.932, de 14 de junho de 2004. Regulamenta a Lei no. 12.930, de 04 de fevereiro, de 2004, que institui o marco regulatório dos programas de parcerias público-privada no âmbito do Estado de Santa Catarina, entre outras providências. Disponível em: < http://www.planejamento.gov.br/secretarias/upload/Arquivos/ppp/legislacao/estadual/lei_1932_20 04.pdf> Acesso em 08 nov. 2012.

30 BRASIL. Lei $n^{\circ} 11.079$, de 30 de dezembro de 2004. Institui normas gerais para licitação e contratação de parceria público-privada no âmbito da administração pública. Disponível em: <http://www.planalto.gov.br/ccivil_03/_ato2004-2006/2004/lei/l11079.htm>. Acesso em: 08 nov. 2012.

31 BRASIL. Constituição (1988). Constituição da República Federativa do Brasil. Brasília, DF: Senado Federal: Centro Gráfico, 1988. 
HASSE, Franciane. A dimensão constitucional dos Princípio do Contraditório e da Ampla Defesa das pessoas jurídicas de direito privado perante os Tribunais de Contas da União (TCU) e Tribunal de Contas do Estado de Santa Catarina (TCESC). Revista Eletrônica Direito e Política, Programa de Pós-Graduação Stricto Sensu em Ciência Jurídica da UNIVALI, Itajaí, v.10, n.2, 10 quadrimestre de 2015. Disponível em: www.univali.br/direitoepolitica - ISSN 1980-7791.

De acordo com o artigo 73 da Constituição Federal/88, o Tribunal de Contas da União é composto por nove Ministros, sendo sua sede no Distrito Federal, com jurisdição em todo o território nacional. ${ }^{32}$

A denúncia referente irregularidades ou ilegalidades poderá ser realizada perante o Tribunal de Contas da União por qualquer cidadão, partido político, associação ou sindicato.

Assim, compete ao Tribunal de Contas, dentre outras funções, julgar as contas dos administradores da administração direta e indireta, dos demais responsáveis pelos valores públicos, e de quem der causa a extravio, perda ou outra irregularidade de que resulte prejuízo ao erário público; apreciar a legalidade dos atos de admissão de pessoal nas entidades referidas e; aplicar, em caso de ilegalidade de despesas ou contas, as sanções previstas em lei, onde, suas decisões de imputação de débito ou multa terão eficácia de título executivo, conforme 0 artigo 71, §30 da Constituição Federal/88. ${ }^{33}$

Salienta-se que o Tribunal de Contas não integra o Poder Judiciário, sendo que seus atos apresentam natureza puramente administrativa, visto que a atividade administrativa pode dispensar o requerimento do interessado, agindo de ofício, não tendo uma lide entre as partes, pois visa satisfazer as necessidades individuais e coletivas, diferentemente da atividade jurisdicional, que depende de iniciativa da parte interessada mediante o ajuizamento de uma ação.

Desta forma, verifica-se que os Tribunais de Contas são órgãos especializados, compostos por pessoas qualificadas para desempenhar a função institucional.

Sendo assim, o processo de exame e validação será efetuado por meio de auditorias executadas pelo Tribunal de Contas.

Sempre que necessário, o Tribunal de Contas poderá solicitar os documentos para análise, podendo inclusive, solicitar a cópia do edital de licitação já

\footnotetext{
32 BRASIL. Constituição (1988). Constituição da República Federativa do Brasil. Brasília, DF: Senado Federal: Centro Gráfico, 1988.

${ }^{33}$ BRASIL. Constituição (1988). Constituição da República Federativa do Brasil. Brasília, DF: Senado Federal: Centro Gráfico, 1988.
} 
HASSE, Franciane. A dimensão constitucional dos Princípio do Contraditório e da Ampla Defesa das pessoas jurídicas de direito privado perante os Tribunais de Contas da União (TCU) e Tribunal de Contas do Estado de Santa Catarina (TCESC). Revista Eletrônica Direito e Política, Programa de Pós-Graduação Stricto Sensu em Ciência Jurídica da UNIVALI, Itajaí, v.10, n.2, 10 quadrimestre de 2015. Disponível em: www.univali.br/direitoepolitica - ISSN 1980-7791.

publicado, até o último dia útil imediatamente anterior à data designada no instrumento convocatório para o recebimento das propostas (artigo 113, §20 da Lei $n^{\circ} 8.666$, de 21 de junho de 1993). ${ }^{34}$

Assim, havendo irregularidades, e sendo determinado pelo Tribunal de Contas, a Administração Pública deverá adotar as medidas corretivas cabíveis. Se o Tribunal não devolver o edital a tempo da abertura da licitação, a Administração deverá suspender a licitação até que haja conclusão de sua análise.

Desta forma, as atividades exercidas pelo Tribunal de Contas da União serão reduzidas a termo, em relatórios, e encaminhadas ao Congresso Nacional trimestral e anualmente.

Qualquer pessoa jurídica de direito privado, que obtenha recursos oriundos do Poder Público, estará sujeita à fiscalização pelo Tribunal de Contas, devendo prestar contas.

Para elucidar a garantia do contraditório e da ampla defesa perante os Tribunais de Contas, o enunciado da Súmula Vinculante $n^{\circ} 3$, do Supremo Tribunal Federal (STF), traz o seguinte teor:

Nos processos perante o Tribunal de Contas da União asseguram-se o contraditório e a ampla defesa quando da decisão puder resultar anulação ou revogação de ato administrativo que beneficie o interessado, excetuada a apreciação da legalidade do ato de concessão inicial de aposentadoria, reforma e pensão. ${ }^{35}$

A Lei Orgânica do Tribunal de Contas da União, Lei $n^{\circ} 8.443$, de 16 de julho de 1992 e a Resolução n 35, de 30 de agosto de 1995, estabelecem os

\footnotetext{
${ }^{34}$ BRASIL. Lei $n^{\circ} 8.666$, de 21 de junho de 1993. Institui normas para licitações e contratos da Administração Pública. Disponível em: <http://www.planalto.gov.br/ccivil_03/leis/L8666cons.htm>. Acesso em: 08 nov. 2012.

35 BRASIL. Supremo Tribunal Federal. Súmula Vinculante $n^{\circ}$ 03. Sessão plenária de 30 de maio de 2007. em: <http://http://www.stf.jus.br/portal/jurisprudencia/listarJurisprudencia.asp?s1=3.NUME.\%20E\%2 0S.FLSV.\&base=baseSumulasVinculantes>. Acesso em 12 nov. 2012.
} 
HASSE, Franciane. A dimensão constitucional dos Princípio do Contraditório e da Ampla Defesa das pessoas jurídicas de direito privado perante os Tribunais de Contas da União (TCU) e Tribunal de Contas do Estado de Santa Catarina (TCESC). Revista Eletrônica Direito e Política, Programa de Pós-Graduação Stricto Sensu em Ciência Jurídica da UNIVALI, Itajaí, v.10, n.2, 10 quadrimestre de 2015. Disponível em: www.univali.br/direitoepolitica - ISSN 1980-7791.

procedimentos a serem adotados, inclusive sobre o exercício do contraditório e da ampla defesa no âmbito do Tribunal de Contas da União. ${ }^{36}$

A Constituição Federal de 1988 (art. 5²) assegura aos litigantes, em processo judicial ou administrativo, o contraditório e a ampla defesa, com os meios e recursos a ela inerentes. ${ }^{37}$

Assim, considerando-se o início dos dizeres da Súmula Vinculante $n^{\circ} 3$, supracitada, no processo submetido à jurisdição do Tribunal de Contas da União, visto ser no âmbito administrativo, após a determinação da citação, insere-se o exercício do direito do contraditório ou da ampla defesa, através da resposta das alegações realizadas.

Verifica-se que a ampla defesa consiste em se reconhecer ao acusado o direito de saber que está sendo processado e qual o motivo, de ter vista dos autos do processo administrativo, de apresentar sua defesa preliminar, de indicar as provas que entender necessárias à sua defesa, de constituir advogado, de oferecer defesa final e recorrer.

O contraditório, princípio que também norteia o processo administrativo exige que, em cada etapa do processo, as partes tenham a oportunidade de apresentar suas razões e suas provas, de forma igualitária para ambas as partes.

Todos os processos realizados pelo Tribunal de Contas são gratuitos, não havendo cobrança de custas ou de preparo, mas seguem etapas como nos demais processos judiciais, como a admissibilidade, a instrução, o parecer do Ministério Público, o julgamento ou apreciação e recursos.

A pessoa jurídica de direito privado, que possui vinculação com o Poder Público, seja na forma de concessão, permissão ou parceria público-privada, conforme já especificado anteriormente, possui responsabilidade sobre os serviços prestados,

\footnotetext{
${ }^{36}$ BRASIL. Lei $n^{\circ} 8.443$, de 16 de julho de 1992. Dispõe sobre a Lei Orgânica do Tribunal de Contas da União. Disponível em: <http://www.planalto.gov.br/ccivil_03/leis/L8443.htm>. Acesso em: 08 nov. 2012.

37 BRASIL. Constituição (1988). Constituição da República Federativa do Brasil. Brasília, DF: Senado Federal: Centro Gráfico, 1988.
} 
HASSE, Franciane. A dimensão constitucional dos Princípio do Contraditório e da Ampla Defesa das pessoas jurídicas de direito privado perante os Tribunais de Contas da União (TCU) e Tribunal de Contas do Estado de Santa Catarina (TCESC). Revista Eletrônica Direito e Política, Programa de Pós-Graduação Stricto Sensu em Ciência Jurídica da UNIVALI, Itajaí, v.10, n.2, 10 quadrimestre de 2015. Disponível em: www.univali.br/direitoepolitica - ISSN 1980-7791.

sendo, desta forma, considerada responsável por qualquer irregularidade que resulte prejuízo ao Erário.

Por solicitação do Congresso Nacional, para apuração de denúncias ou por iniciativa própria, o Tribunal realizará auditorias e inspeções, com o intuito de capturar dados e informações, analisar, produzir um diagnóstico e formar um juízo de valor.

Todo o procedimento submetido à deliberação do Tribunal de Contas será organizado em processo, porém, suas decisões são meros atos administrativos.

Verifica-se que o Tribunal de Contas atua com independência, imparcialidade, seguindo ritos estabelecidos por lei, respeitando os princípios do contraditório e da ampla defesa, prevendo possibilidades de recursos.

O $\S 4^{\circ}$, do artigo 53 da Lei $n^{\circ} 8.443$, de 16 de julho de 1992, designa:

Art. $53[\ldots]$

§4 Reunidas as provas que indiquem a existência de irregularidade ou ilegalidade, serão públicos os demais atos do processo, assegurando-se aos acusados a oportunidade de ampla defesa. ${ }^{38}$

Assim, poderá ser fornecida cópia de processo, para fins de informações para defesa da pessoa jurídica auditada, a qual ocorrerá na etapa de instrução (artigos $3^{\circ}$ e 10 , da Resolução n 35/1995). ${ }^{39}$

Já na etapa de julgamento ou apreciação de processo, permite-se a sustentação oral, pessoalmente ou por procurador devidamente credenciado, desde que haja requisição ao Presidente do respectivo colegiado até o início da sessão. O prazo para a referida sustentação será de 15 (quinze) minutos, podendo ser

${ }^{38}$ BRASIL. Lei $\mathbf{n}^{\circ} \mathbf{8 . 4 4 3}$, de 16 de julho de 1992. Dispõe sobre a Lei Orgânica do Tribunal de Contas da União. Disponível em: <http://www.planalto.gov.br/ccivil_03/leis/L8443.htm>. Acesso em: 08 nov. 2012.

39 BRASIL. Resolução n 35, de 30 de agosto de 1995. Estabelece procedimentos sobre o exercício da ampla defesa no âmbito do Tribunal de Contas da União. Disponível em: <http://portal2.tcu.gov.br/portal/page/portal/TCU/eTCU/orientacoes/RES1995_036.pdf>. Acesso em: 08 nov. 2012. 
HASSE, Franciane. A dimensão constitucional dos Princípio do Contraditório e da Ampla Defesa das pessoas jurídicas de direito privado perante os Tribunais de Contas da União (TCU) e Tribunal de Contas do Estado de Santa Catarina (TCESC). Revista Eletrônica Direito e Política, Programa de Pós-Graduação Stricto Sensu em Ciência Jurídica da UNIVALI, Itajaí, v.10, n.2, 10 quadrimestre de 2015. Disponível em: www.univali.br/direitoepolitica - ISSN 1980-7791.

prorrogado por igual período. Não há obrigatoriedade de constituir advogado, mas a legislação assegura este direito às partes (artigo 14 e parágrafos, da Resolução n’ 35/1995). ${ }^{40}$

Se houver necessidade, a pessoa jurídica poderá solicitar certidão e demais informações necessárias para embasar sua defesa, desde que haja requerimento fundamentado ao Presidente do colegiado (artigo 15 e seguintes, da Resolução $\left.n^{\circ} 35 / 1995\right) .{ }^{41}$

Entretanto, o responsável poderá ser afastado, temporariamente, de suas funções, se houverem indícios de que possa dificultar a realização da auditoria ou inspeção, causar novos danos ao Erário ou inviabilizar o seu ressarcimento (artigo 18 da Resolução n 35/1995). ${ }^{42}$

E, constatando-se a ilegalidade ou irregularidade, o Tribunal fixará prazo para cumprimento da lei. No caso de ato administrativo, quando não atendido, será determinada a sustação do ato impugnado, comunicando a decisão à Câmara dos Deputados e ao Senado Federal e aplicando multa ao responsável. No caso de contrato, quando não atendido, o Tribunal comunicará ao Congresso Nacional, que terá um prazo de 90 (noventa) dias para adotar o ato de sustação e demais medidas cabíveis. Se nesse prazo, não forem efetivadas as medidas cabíveis, o Tribunal decidirá a respeito da sustação do contrato (Artigo 19 da Resolução nº $35 / 1995^{43}$ e Artigo 45 da Lei $n^{\circ} 8.443 / 1992^{44}$ ).

40 BRASIL. Resolução $\mathbf{n}^{\circ} \mathbf{3 5}$, de 30 de agosto de 1995. Estabelece procedimentos sobre o exercício da ampla defesa no âmbito do Tribunal de Contas da União. Disponível em: <http://portal2.tcu.gov.br/portal/page/portal/TCU/eTCU/orientacoes/RES1995_036.pdf>. Acesso em: 08 nov.2012.

${ }^{41}$ BRASIL. Resolução $\mathbf{n}^{\circ}$ 35, de 30 de agosto de 1995. Estabelece procedimentos sobre o exercício da ampla defesa no âmbito do Tribunal de Contas da União. Disponível em: <http://portal2.tcu.gov.br/portal/page/portal/TCU/eTCU/orientacoes/RES1995_036.pdf>. Acesso em: 08 nov.2012.

42 BRASIL. Resolução $\mathbf{n}^{\circ}$ 35, de 30 de agosto de 1995. Estabelece procedimentos sobre o exercício da ampla defesa no âmbito do Tribunal de Contas da União. Disponível em: <http://portal2.tcu.gov.br/portal/page/portal/TCU/eTCU/orientacoes/RES1995_036.pdf>. Acesso em: 08 nov.2012.

43 BRASIL. Resolução $\mathbf{n}^{\circ}$ 35, de 30 de agosto de 1995. Estabelece procedimentos sobre o exercício da ampla defesa no âmbito do Tribunal de Contas da União. Disponível em: <http://portal2.tcu.gov.br/portal/page/portal/TCU/eTCU/orientacoes/RES1995_036.pdf>. Acesso em: 08 nov.2012. 
HASSE, Franciane. A dimensão constitucional dos Princípio do Contraditório e da Ampla Defesa das pessoas jurídicas de direito privado perante os Tribunais de Contas da União (TCU) e Tribunal de Contas do Estado de Santa Catarina (TCESC). Revista Eletrônica Direito e Política, Programa de Pós-Graduação Stricto Sensu em Ciência Jurídica da UNIVALI, Itajaí, v.10, n.2, 10 quadrimestre de 2015. Disponível em: www.univali.br/direitoepolitica - ISSN 1980-7791.

Por fim, o Ministro-Relator do Tribunal de Contas deverá emitir relatório, onde constem as decisões fundamentadas. A decisão definitiva do Tribunal de Contas da União é exarada via acórdão, publicado no Diário Oficial da União, sendo notificado, o responsável, para que recolha a importância devida.

De todas as decisões e acórdãos adotados pelo Tribunal, cabem recursos, possibilitando que em cada etapa o responsável tenha a garantia do contraditório e da ampla defesa.

Vale aqui ressaltar que os Tribunais de Contas Estaduais passaram a exercer atribuições semelhantes ao Tribunal de Contas da União, dentro de sua esfera de atuação.

As irregularidades que envolvam recursos públicos estaduais ou municipais devem ser levadas ao conhecimento do Tribunal de Contas do Estado ou do Município correspondente.

Assim, quando um gasto é realizado com recursos do orçamento estadual, a fiscalização cabe ao Tribunal de Contas Estadual. Entretanto, quando os gastos das prefeituras ou dos governos estaduais forem efetuados com recursos federais, a fiscalização ficará a cargo do Tribunal de Contas da União. Isto ocorre quando o Governo Federal repassa recursos aos estados e municípios, através de convênios, acordos e ajustes, devendo, portanto, o Tribunal de Contas da União, fiscalizar a sua aplicação.

Entretanto, salienta-se que o Tribunal de Contas da União serve como paradigma para a organização e o funcionamento dos demais Tribunais de Contas.

\section{CONSIDERAÇÕES FINAIS}

Pelo presente estudo verifica-se a importância do princípio constitucional do contraditório e da ampla defesa, considerando-se que é direito da parte a

${ }^{44}$ BRASIL. Lei $\mathbf{n}^{\circ} \mathbf{8 . 4 4 3}$, de 16 de julho de 1992. Dispõe sobre a Lei Orgânica do Tribunal de Contas da União. Disponível em: <http://www.planalto.gov.br/ccivil_03/leis/L8443.htm>. Acesso em: 08 nov. 2012. 
HASSE, Franciane. A dimensão constitucional dos Princípio do Contraditório e da Ampla Defesa das pessoas jurídicas de direito privado perante os Tribunais de Contas da União (TCU) e Tribunal de Contas do Estado de Santa Catarina (TCESC). Revista Eletrônica Direito e Política, Programa de Pós-Graduação Stricto Sensu em Ciência Jurídica da UNIVALI, Itajaí, v.10, n.2, 10 quadrimestre de 2015. Disponível em: www.univali.br/direitoepolitica - ISSN 1980-7791.

oportunidade de resposta, afim de que exponha suas razões decorrentes do processo em questão.

Em razão disto, as partes têm o direito ao conhecimento da existência da ação e todos os atos do processo, assim como a possibilidade de reagirem aos atos que Ihe sejam desfavoráveis, mesmo em processos administrativos.

Portanto, em qualquer processo (judicial ou administrativo), esta garantia constitucional do contraditório permite que as partes tomem conhecimento de todos os atos, com a possibilidade de manifestação sobre os mesmos, e, a ampla defesa garante o exercício da plena defesa em todos os momentos do processo, com a possibilidade de produção de provas a fim de confirmarem suas alegações, bem como interpor recursos em face das decisões.

Por sua vez, agregam-se ao estudo os institutos passíveis de contratação com o Poder Público, quais sejam: concessão, permissão e parceria público-privada.

Desta forma, devido ao elevado número de serviços necessários para suprir os anseios da coletividade, verifica-se que o Poder Público não possui meios suficientes para cumpri-los, sendo necessário contratar particulares para a execução de tais serviços.

Mas como são serviços públicos, os particulares não possuem sua titularidade, que permanece com o Poder Público, mas tornam-se responsáveis por sua execução e por qualquer irregularidade que venha a ter.

Entretanto, para que tais contratos sejam formalizados, devem ser precedidos de licitação, através da modalidade concorrência, que determinará os procedimentos, atividades necessárias, responsabilidades, dentre outros atributos, devidamente dispostos na minuta do contrato, que deverá acompanhar o edital.

No caso da concessão e permissão, os concessionários e permissionários serão remunerados através das tarifas impostas aos usuários, que serão devidamente quantificadas no procedimento licitatório. No caso das parcerias público-privadas, 
HASSE, Franciane. A dimensão constitucional dos Princípio do Contraditório e da Ampla Defesa das pessoas jurídicas de direito privado perante os Tribunais de Contas da União (TCU) e Tribunal de Contas do Estado de Santa Catarina (TCESC). Revista Eletrônica Direito e Política, Programa de Pós-Graduação Stricto Sensu em Ciência Jurídica da UNIVALI, Itajaí, v.10, n.2, 10 quadrimestre de 2015. Disponível em: www.univali.br/direitoepolitica - ISSN 1980-7791.

os parceiros serão remunerados pelo Poder Público, através de um fundo próprio para tal fim.

Cada instituto deve seguir os procedimentos dispostos em legislação específica, sendo que, no caso da parceria público-privada, o Estado-membro ou Município pode legislar a respeito, com embasamento na lei federal específica.

Quanto à fiscalização destes contratos, ficará a cargo do Tribunal de Contas, que poderá ser motivado através de denúncia realizada por qualquer cidadão, partido político, associação ou sindicato.

O oferecimento de denúncia é papel fundamental no fortalecimento da cidadania e na defesa dos interesses sociais, sendo um meio importante de colaboração com o controle.

O Tribunal de Contas poderá efetuar auditorias nas pessoas jurídicas de direito privado, a fim de levantar se há irregularidades em seus atos, instaurando processo administrativo, que seguirá os trâmites determinados por lei.

Para saber qual Tribunal de Contas deve atuar em cada caso, deve-se identificar de qual ente da federação advém o recurso disponibilizado para a realização de um determinado serviço.

Assim, o Tribunal de Contas da União é o órgão de controle externo que fiscaliza os gastos dos recursos públicos federais, ou seja, os recursos provenientes da União. Destarte, se houver alguma irregularidade envolvendo recursos federais, repassados aos Estados ou municípios, o Tribunal de Contas da União será o responsável pela fiscalização.

Caso o recurso advenha do Governo Estadual, o Tribunal de Contas Estadual será o responsável pela fiscalização.

O Tribunal de Contas não é um órgão jurisdicional, portanto, seus processos serão tramitados no âmbito administrativo. 
HASSE, Franciane. A dimensão constitucional dos Princípio do Contraditório e da Ampla Defesa das pessoas jurídicas de direito privado perante os Tribunais de Contas da União (TCU) e Tribunal de Contas do Estado de Santa Catarina (TCESC). Revista Eletrônica Direito e Política, Programa de Pós-Graduação Stricto Sensu em Ciência Jurídica da UNIVALI, Itajaí, v.10, n.2, 10 quadrimestre de 2015. Disponível em: www.univali.br/direitoepolitica - ISSN 1980-7791.

Mas vale ressaltar, que mesmo sendo processo administrativo, as partes podem ter acesso aos documentos constantes nos autos, visando à oportunidade de oferecer o contraditório e a ampla defesa.

O direito ao contraditório e a ampla defesa é um direito assegurado pela Constituição, tanto em processo judicial quanto administrativo, o que possibilita que seja aplicado aos processos administrativos impetrados perante o Tribunal de Contas da União.

É importante que cada uma das partes envolvidas tenha conhecimento dos procedimentos realizados, para que, de forma igualitária, possa apresentar defesa referente às alegações instituídas.

Perante o exposto, conclui-se que, se alguma pessoa jurídica de direito privado, que venha a obter recursos do Poder Público para execução de algum serviço, como nos contratos de concessão, permissão ou parceria público-privada, for auditada pelo Tribunal de Contas, diante de qualquer decisão deste, no decorrer até a finalização do processo, terá o direito à resposta, ou seja, terá a garantia ao contraditório e a ampla defesa, no âmbito do Tribunal de Contas.

\section{REFERÊNCIAS DAS FONTES CITADAS}

BRASIL. Constituição (1988). Constituição da República Federativa do Brasil. Brasília, DF: Senado Federal: Centro Gráfico, 1988.

BRASIL. DECRETO No 1.932, de 14 de junho de 2004. Regulamenta a Lei no. 12.930, de 04 de fevereiro, de 2004, que institui o marco regulatório dos programas de parcerias público-privada no âmbito do Estado de Santa Catarina, entre outras providências. Disponível em: <http://www.planejamento.gov.br/secretarias/upload/Arquivos/ppp/legislacao/e stadual/lei_1932_2004.pdf> Acesso em 08 nov. 2012.

BRASIL. Lei $\mathbf{n}^{\circ} \mathbf{8 . 4 4 3}$, de 16 de julho de 1992. Dispõe sobre a Lei Orgânica do Tribunal de Contas da União. Disponível em: 
HASSE, Franciane. A dimensão constitucional dos Princípio do Contraditório e da Ampla Defesa das pessoas jurídicas de direito privado perante os Tribunais de Contas da União (TCU) e Tribunal de Contas do Estado de Santa Catarina (TCESC). Revista Eletrônica Direito e Política, Programa de Pós-Graduação Stricto Sensu em Ciência Jurídica da UNIVALI, Itajaí, v.10, n.2, 10 quadrimestre de 2015. Disponível em: www.univali.br/direitoepolitica - ISSN 1980-7791.

<http://www.planalto.gov.br/ccivil_03/leis/L8443.htm>. Acesso em: 08 nov. 2012.

BRASIL. Lei $\mathbf{n}^{\circ} \mathbf{8 . 6 6 6}$, de 21 de junho de 1993. Institui normas para licitações e contratos da Administração Pública. Disponível em: <http://www.planalto.gov.br/ccivil_03/leis/L8666cons.htm>. Acesso em: 08 nov. 2012.

BRASIL. Lei n` 8.987, de 13 de fevereiro de 1995. Estabelece o regime de concessão e permissão da prestação de serviços públicos. Disponível em: <http://www.planalto.gov.br/ccivil_03/leis/L8987cons.htm>. Acesso em: 08 nov. 2012.

BRASIL. Resolução $\mathbf{n}^{\circ} \mathbf{3 5}$, de 30 de agosto de 1995. Estabelece procedimentos sobre o exercício da ampla defesa no âmbito do Tribunal de Contas da União. Disponível em: <http://portal2.tcu.gov.br/portal/page/portal/TCU/eTCU/orientacoes/RES1995_0 36.pdf>. Acesso em: 08 nov.2012.

BRASIL. Lei n 11.079, de 30 de dezembro de 2004. Institui normas gerais para licitação e contratação de parceria público-privada no âmbito da administração pública. Disponível em: <http://www.planalto.gov.br/ccivil_03/_ato2004-2006/2004/lei/l11079.htm> . Acesso em: 08 nov. 2012.

BRASIL. Supremo Tribunal Federal. Súmula Vinculante $\mathbf{n}^{\circ} \mathbf{0 3}$. Sessão plenária de 30 de maio de 2007. Disponível em: <http://http://www.stf.jus.br/portal/jurisprudencia/listarJurisprudencia.asp?s1= 3. NUME.\%20E\%20S.FLSV.\&base=baseSumulasVinculantes>. Acesso em 12 nov. 2012.

BRASIL. Tribunal de Contas da União. Institucional: conheça o TCU. Disponível em:

<http://portal2.tcu.gov.br/portal/page/portal/TCU/institucional/conheca_tcu/hist oria>. Acesso em 12 nov. 2012. 
HASSE, Franciane. A dimensão constitucional dos Princípio do Contraditório e da Ampla Defesa das pessoas jurídicas de direito privado perante os Tribunais de Contas da União (TCU) e Tribunal de Contas do Estado de Santa Catarina (TCESC). Revista Eletrônica Direito e Política, Programa de Pós-Graduação Stricto Sensu em Ciência Jurídica da UNIVALI, Itajaí, v.10, n.2, 10 quadrimestre de 2015. Disponível em: www.univali.br/direitoepolitica - ISSN 1980-7791.

GASPARINI, Diógenes. Direito administrativo. 15. ed. atual. por Fabrício Mottal. São Paulo: Saraiva, 2010.

GRINOVER, Ada Pellegrini. 0 processo constitucional em marcha: contraditório e ampla defesa em cem julgados do tribunal de alçada criminal de São Paulo. São Paulo: Max Limonad, 1985.

JUSTEN FILHO, Marçal. Teoria geral das concessões de serviço público. São Paulo: Dialética, 2003.

MELLO, Celso Antônio Bandeira de. Curso de direito administrativo. 17. ed. rev. e atual. São Paulo: Malheiros Editores, 2004.

MELLO, Celso Antônio Bandeira de. Curso de direito administrativo. 25. ed. rev. e atual. São Paulo: Malheiros Editores, 2007.

MUKAI, Sylvio Toshiro. Parcerias público-privadas: comentários à Lei Federal n० 11.079/04, às Leis Estaduais de Minas Gerais, Santa Catarina, São Paulo, Distrito Federal, Goiás, Bahia, Ceará, Rio Grande do Sul e à Lei Municipal de Vitória/ES. Rio de Janeiro: Forense Universitária, 2005.

SANTOS, Moacyr Amaral. Primeiras linhas de direito processual civil. v. 2. 23. ed. rev. e atual. São Paulo: Saraiva, 2004.

SILVA, de Plácido. Vocabulário jurídico. 26. ed. SLAIBI FILHO. Nagib; CARVALHO. Gláucia. (atualizadores). Rio de Janeiro: Forense, 2005. p. 721.

THEODORO, Junior, Humberto. Curso de direito processual civil. Rio de Janeiro: Forense, 2004.

WAMBIER, Luiz Rodrigues. et al. Curso avançado de processo civil: teoria geral do processo e processo de conhecimento. v. 1. 8. ed. rev., atual. eampl. São Paulo: Editora Revista dos Tribunais, 2006.b

Submetido em: Março/2015

Aprovado em: Abril/2015 